\title{
SELENIUM IN CERTAIN FINNISH SEDIMENTS
}

\author{
Tapio Koljonen
}

Koljonen, Tapio 1974: Selenium in certain Finnish sediments. Bull. Geol. Soc. Finland 46, 15-21.

\begin{abstract}
Almost 100 sediments, mostly Finnish, have been analyzed for selenium. Tentative values for the average selenium contents of the various groups are given. The distribution of the element in the sediments studied is interpreted as follows. During weathering of selenium-bearing sulphides, Eh-pH conditions favor liberation of elemental selenium, which is then adsorbed and concentrated in clays and organic colloids. Residual sediments contain mostly feldspar and quartz and are devoid of selenium; their specific content depends on the colloids and fine clayey fractions present. Cultivation appears to increase selenium content, this increase being particularly noticeable in peat soils, which originally contain very little selenium.
\end{abstract}

Tapio Koljonen, Department of Geology and Mineralogy, University of Helsinki, SF-00170 Helsinki 17, Finland.

\section{Introduction}

Previous studies on the sedimentary geochemistry of selenium have mostly been restricted to the abundance and occurrence of the element in volcanic soils and in soils where selenium is found in toxic concentrations. To the author's knowledge, little information is available on the distribution of selenium in the soils of Fennoscandia. For that reason, a number of analyses were carried out on various types of sediments, mainly from Finland. The behavior of selenium in soilforming processes and its correlation to the underlying bedrock will be dealt with in detail on a later occasion.

\section{Sampling and analytical procedure}

Soil specimens were collected mostly from the middle and southern parts of Finland and analyzed as described by the author (1973a). In this procedure, the organic part is dissolved in nitric and perchloric acids, after which mineral part is decomposed by fusing the soil with a mixture of $\mathrm{NaOH}-\mathrm{Na}_{2} \mathrm{O}_{2}$. The flux and solution are then combined, and the selenium is distilled as $\mathrm{SeBr}_{2}$. Thus selenium is quantitatively separated from the bulk of a sample and analyzed colorimetrically without the interference of other elements. Some results of this method are presented in Table 1 and calculated to the oven $\operatorname{dry}\left(110^{\circ} \mathrm{C}\right)$ weight. 
In the following, the selenium contents found in various sediments are briefly reviewed and compared with the known behavior of selenium in sediments.

\section{Unsorted sediments, tills}

Selenium contents in tills are set out in Fig. 1 and Table 1, Nos. 1-10.

The tills investigated are of fine grain size $(<1 \mathrm{~mm})$ and the selenium content is between the maximum and minimum values found in sorted sediments. The average content has probably decreased since the time of initial deposi-
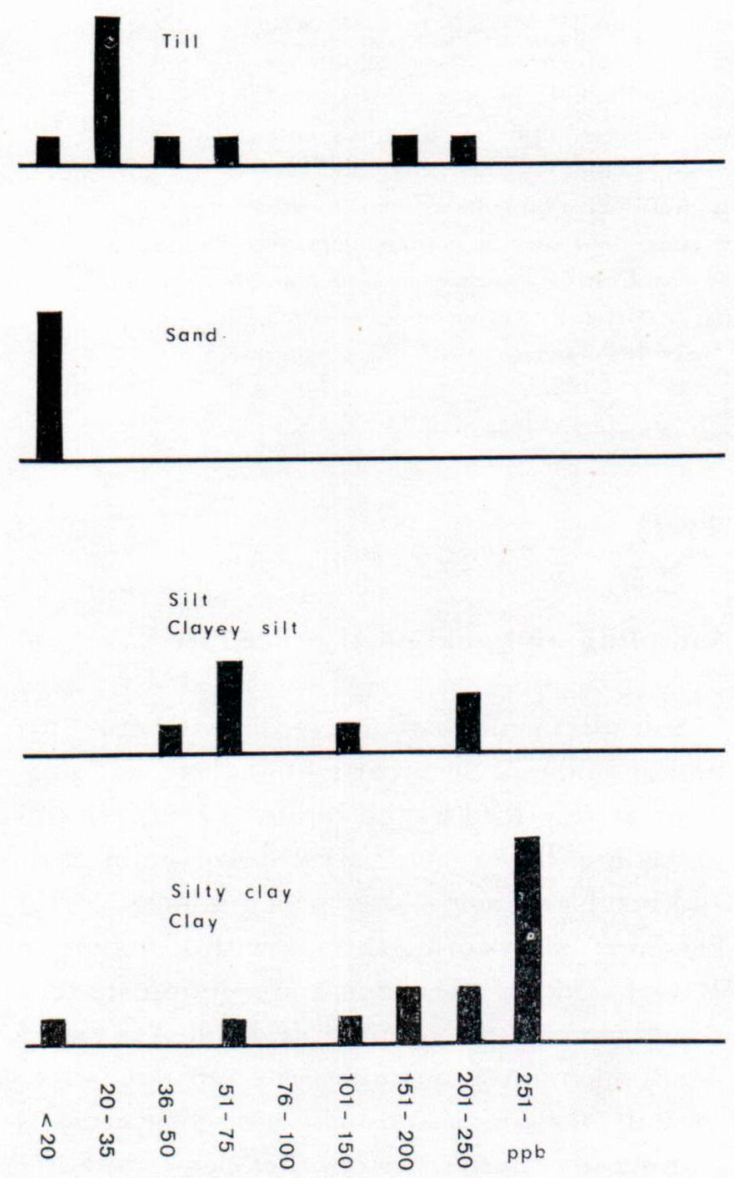

Fig. 1. Review of the selenium contents in unsorted and sorted sediments ( one sample). tion of the glacial material, owing to the fact that selenium is concentrated in melanocratic rocks (Koljonen 1973b), which disintegrate more easily than do leucocratic rocks. The dissolved selenium may then migrate into hydrolysates, oxidates (Goldschmidt and Strock 1935, 138; Koljonen 1965), or organic sediments.

\section{Sorted sediments}

The distribution of selenium in sorted sediments is represented in Fig. 1 and Table 1, Nos. 11-36. The following specimens have been included in the figure:

$$
\begin{array}{lcc}
\text { Sand } & \text { Nos. } 11-15 \\
\text { Silt, Clayey silt } & \text { » } & 16-22 \\
\text { Silty clay, Clay } & \text { » } 23-36
\end{array}
$$

Although the number of samples is rather small, the histograms (Fig. 1) reveal a clear trend in the distribution of selenium among the different groups of sediments. In sands, which contain predominantly quartz and feldspars, the selenium concentration is $<10 \mathrm{ppb}$, below the lower limit of the analytical method used. Through mechanical disintegration and weathering the mafic minerals and sulphides ( $c f$. Baker 1973) are usually concentrated in the most fine-grained fractions and these fractions contain the greatest percentage of selenium (Koljonen 1973b; c). The most resistant silicate minerals are greatly depleted in selenium.

In solution, selenium is easily oxidized into its elemental form, which is electrically charged. Under strongly oxidizing conditions it may be converted to selenite ( $c f$. Delahay et al. 1952), which easily migrates in solution.

Fig. 1 shows that clays are greatly enriched with selenium. A remarkable feature is that, under weathering conditions, selenium does not easily migrate far in the humid, relatively cold climate and mostly acid milieu that prevail in Finland. Rather it is removed from solution and adsorbed into sediments. 


\section{Mineral soils containing bumus}

The mineral parts of topsoils are formed chiefly from tills and to a lesser degree from sorted sediments. Only in coastal areas and in inland areas near lakes and rivers are soils apt to contain appreciable amounts of clay. Such soils are commonly under cultivation and tend to contain more clay than those found in forest areas. Moreover, their organic part is more humified than that of topsoils found under the coniferous forests that prevail in Finland. The forest topsoil contains more unhumified litter and little polymerized organic acid and tends to be more acidic than cultivated soils, with the possible exception of peat soils.

The terms used in this study for classification of soils containing organic matter are:

Topsoil, raw humus: the uppermost part of the soil under coniferous forest, containing soil particles and humified remains of vegetation.

Topsoil, forest mull humus: the soil under herbaceous forest, containing humified matter and soil particles.

Mull humus: soil containing much highly polymerized humic acid along with plant remains. Commonly its clay content is higher than that of other soils. This soil is or has been under cultivation.

Being a plant nutrient, selenium is accumulated by organisms. Its behavior in organic life has been treated extensively in the literature and the most comprehensive reviews have been published by Trelease and Beath (1949) and Rosenfeld and Beath (1964).

The occurrence of selenium in soils containing organic matter is given in Fig. 2 and Table 1, Nos. 37-64.

Selenium seems to be enriched in areas which are cultivated or have been used as pasture. On the average, such soils contain more clay than do forest soils and therefore, by adsorption, can more successfully prevent the migration of selenium. Probably part of the selenium present is introduced through synthetic fertilizers and manure.

The organic soils (Table 1, Nos. 37-42, 44) under coniferous forests are enriched with selenium. Presumably, when freed from organic detritus, selenium is in elemental form in an acid milieu and therefore migrates with difficulty. Under herbaceous forests, where soils (Table 1, Nos. 43,45$)$ are not as acid as under coniferous forests, selenium, being in a more oxidized form, may migrate more easily and therefore be depleted. The mobility of selenium has been studied in a basic milieu, especially in areas where limestone prevails. Supposedly, because calcium selenite is easily soluble (Leutwein 1972, 34-L-1), such soils may contain selenium in concentrations toxic for livestock (Walsh et al. 1951; Fleming and Walsh 1957).

\section{Organic sediments}

Organic sediments may be divided into two types:

Peats: sediments mostly formed of humified bryophyte and carex.

Gyttjas and dys: sediments formed on lake bottoms and related environments and which contain more or less humified organic remains along with soil particles.

Selenium contents for the investigated organic sediments are presented in Fig. 2 and Table 1, Nos. $65-78$.

Only little selenium is found in uncultivated peat soils (Table 1, Nos. 68-73). Probably peats formed on lake shores (Table 1, No. 66) where vegetation also flourishes obtain their trace elements from the circulating water. Such an area is often submerged as a result of spring and autumn floods and, during this time, the detritus sediments deposited on the vegetation further increase their nutrient content. Under normal conditions, peats, which do not receive selenium from the surrounding area, are very much depleted: only by cultivation is their content of selenium increased. 

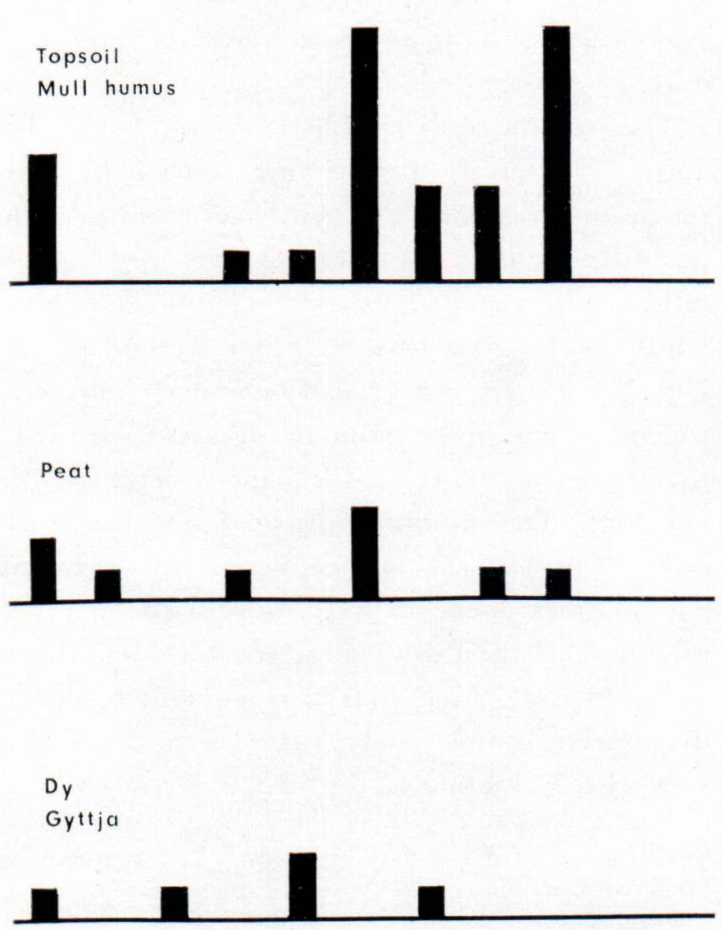

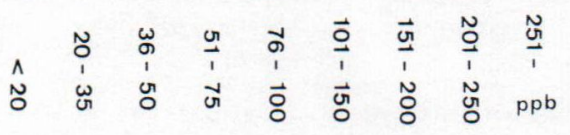

Fig. 2. Review of the selenium contents in soils containing organic matter ( $\square$ one sample).

The lake sediments analyzed are of two types: Table 1, Nos. 74-76 are sediments from common polyhumic, dystrophic lakes and ponds, whereas Nos. 77 and 78 are bottom sediments from oligotrophic, calcareous environments. The selenium content in the first type is approximately average for sediments. In lakes and ponds, soluble organic compounds, especially fulvic acid and its complex compounds containing cations, are oxidized near the surface. Forming charged humus colloids, they then precipitate and settle on the bottom ( $c f$. Carlson 1973), probably accumulating selenium in the process.

The dys and gyttjas contain some selenium (Table 1, Nos. 74-75), even when the surrounding rocks are nearly devoid of it (Se $<10$ $\mathrm{ppb})$. It is therefore probable that part of the selenium present has migrated in in the form of organic compounds and become concentrated through time. Selenium, during its biocycle, appears to be incorporated into proteins and aminoacids (Byers and Knight 1935; Oldfield 1972,174 ), which, because they contain nitrogen are more resistant to disintegration than most other organic compounds. Thus the $\mathrm{C} / \mathrm{N}$ ratio decreases as lake sediments disintegrate. Since selenium enrichment has also been observed in lacustrine sediments, mudstone, bituminous shales, and coals ( $c f$. Beath and Gilbert 1936; Beath et al. 1946; Chentzov 1963; Davidson and Gulbrandsen 1957; Gibson and Selvig 1944; Keys and White 1956; Meixner 1954; Fleming and Walsh 1957; Searight et al. 1946), it seems highly probable that selenium, like sulphur, is enriched into organic residues, which are resistant against weathering.

The gyttjas (Table 1, Nos. 77-78), formed in a calcareous environment, have a low selenium content. In those areas selenium tends to form soluble compounds (Walsh et al. 1951), probably inorganic selenites, that easily migrate out of the system. The sedimentation of humus is small, because the organic acids are neutralized and the organic remains are oxidized and disintegrated. Colloids, which could adsorb and collect selenium, are not formed, and selenium is therefore dissolved into circulating waters until it is removed.

\section{Calcareous detritus sediments}

Samples Nos. 79-82, Table 1, are from the seashore and contain the carbonate remains of the more or less weathered skeletons of recent molluscs as well as some soil particles. The selenium content is less than that commonly found in clayey sediments and nearer to that found in unsorted sediments. The smallest amount is found in No. 82, which is composed of weathered shell with little or no soil. 
TABLE 1

Selenium content of the sediments.

\begin{tabular}{|c|c|c|c|c|c|}
\hline No. & Sediment and locality & $\begin{array}{c}\text { Sclenium } \\
\text { content, } \\
\text { ppb }\end{array}$ & No. & Sediment and locality & $\begin{array}{c}\text { Selenium } \\
\text { content, } \\
\text { ppb }\end{array}$ \\
\hline & Unsorted sediments & & 47 & Mull humus. Petäjävesi, Puttola, Finland $\ldots \ldots \ldots$ & 470 \\
\hline 1 & Clayey till. Helsinki, Herttoniemi, Finland .... & 230 & 48 & Mull humus, cultivated. Kuhmoinen, Patavesi, Finland & 320 \\
\hline 2 & Till. Helsinki, Herttoniemi, Finland .......... & 180 & 49 & Mull humus, cultivated. Helsinki, Viikki, Latokartano, & \\
\hline 3 & Till. Petäjävesi, Puttola, Finland .............. & 68 & & 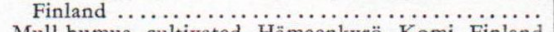 & 320 \\
\hline 4 & Till. Hämeenkyrö, Komi, Majajärvi, Finland ....... & 37 & 50 & Mull humus, cultivated. Hämeenkyrö, Komi, Finland & 290 \\
\hline 5 & Till. Petäjävesi, Puttola, Finland ............. & 33 & 51 & Mull humus, cultivated. Helsinki, Viikki, Latokartano, & \\
\hline 6 & Till. Petäjävesi, Maunula, Finland..$\ldots \ldots \ldots \ldots$ & 26 & & Finland $\ldots \ldots \ldots \ldots \cdots \cdots \cdots \cdots \cdots \cdots \cdots \cdots \cdots \cdots \cdots \cdots \cdots \cdots \cdots \cdots \cdots$ & 260 \\
\hline 7 & Till. Petäjävesi, Puttola, Finland $\ldots \ldots \ldots \ldots \ldots \ldots$ & 23 & 52 & $\begin{array}{l}\text { Mull humus, cultivated. Petäjävesi, Puttola, Konttila, } \\
\text { Finland } \ldots \ldots \ldots \ldots \ldots \ldots \ldots \ldots \ldots \ldots \ldots \ldots \ldots \ldots \ldots\end{array}$ & 230 \\
\hline $\begin{array}{l}8 \\
9\end{array}$ & $\begin{array}{l}\text { Till. Petäjävesi, Maunula, Finland } \ldots \ldots \ldots \ldots \ldots \ldots \\
\text { Till. Helsinki, Herttoniemi, Finland } \ldots \ldots \ldots \ldots \ldots\end{array}$ & $\begin{array}{l}23 \\
21\end{array}$ & 53 & Mull humus, cultivated. Petäjävesi, Vanha-Puttola, & \\
\hline 10 & Till. Petäjävesi, Puttola, Finland $\ldots \ldots \ldots \ldots \ldots \ldots$ & n.d. & 54 & 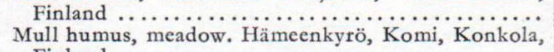 & 230 \\
\hline & Sorted sediments & & 55 & 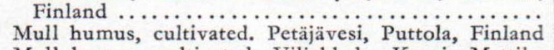 & $\begin{array}{l}210 \\
200\end{array}$ \\
\hline 11 & $\begin{array}{l}\text { Sand, from the ancient sea shore of the Gulf of Finland. } \\
\text { Helsinki, Laajasalo, Yliskylä, Finland ........... }\end{array}$ & n.d. & 56 & $\begin{array}{l}\text { Mull humus, cultivated. Viljakkala, Komi, Mattila, } \\
\text { Finland } \ldots \ldots \ldots \ldots \ldots \ldots \ldots \ldots \ldots \ldots \ldots \ldots \ldots \ldots\end{array}$ & 170 \\
\hline 12 & Sand, glacial outwash. Hämeenkyrö, Komi, Finland & n.d. & 57 & Mull humus. Petäjävesi, Puttola, Maunula, Finland & 160 \\
\hline 13 & Sand, glacial outwash. Hämeenkyrö, Komi, Finland & n.d. & 58 & Mull humus, cultivated. Petäjävesi, Puttola, Maunula, & \\
\hline 14 & Sand, glacial outwash. Petäjävesi, Piesala, Finland ... & n.d. & & 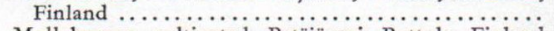 & 150 \\
\hline 15 & $\begin{array}{l}\text { Clayey sand, from the sea shore of the Gulf of Bothnia. } \\
\text { Korsnäs, Finland } \ldots \ldots \ldots \ldots \ldots \ldots \ldots \ldots \ldots \ldots\end{array}$ & & $\begin{array}{l}59 \\
60\end{array}$ & $\begin{array}{l}\text { Mull humus, cultivated. Petäjävesi, Puttola, Finland } \\
\text { Mull humus, cultivated, Hämeenkyrö, Komi. Finland }\end{array}$ & 130 \\
\hline 16 & Silt. Petäjävesi, Puttola, Finland ................. & 240 & 61 & $\begin{array}{l}\text { Mull humus, cultivated. Hameenkyro, Komi, Finland } \\
\text { Mull humus, meadow. Hämeenkyrö, Komi, Mattila, }\end{array}$ & \\
\hline 17 & Silt. Petäjävesi, Puttola, Finland $\ldots \ldots \ldots \ldots \ldots \ldots$ & 110 & & 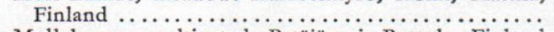 & 110 \\
\hline 18 & $\begin{array}{l}\text { Silt, from the sea shore of the Gulf of Bothnia. Kors- } \\
\text { näs, Finland } \ldots \ldots \ldots \ldots \ldots \ldots \ldots \ldots \ldots \ldots \ldots \ldots\end{array}$ & 68 & $\begin{array}{l}62 \\
63\end{array}$ & $\begin{array}{l}\text { Mull humus, cultivated. Petäjävesi, Puttola, Finland } \\
\text { Mull humus, cultivated. Petäjävesi, Puttola, Finland }\end{array}$ & $\begin{array}{r}110 \\
59\end{array}$ \\
\hline $\begin{array}{l}19 \\
20\end{array}$ & $\begin{array}{l}\text { Silt, cultivated. Helsinki, Viikki, Latokartano, Finland } \\
\text { Silt, from the sea shore of the Gulf of Bothnia. Korsnäs, }\end{array}$ & 68 & 64 & $\begin{array}{l}\text { Mull humus, meadow. Hämeenkyrö, Komi, Mattila, } \\
\text { Finland }\end{array}$ & \\
\hline & 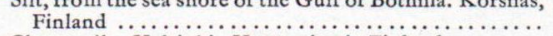 & 42 & 65 & Peat, Sphagnum, cultivated. Petäjävesi, Puttola, Fin- & \\
\hline 21 & Clayey silt. Helsinki, Herttoniemi, Finland ....... & 220 & & 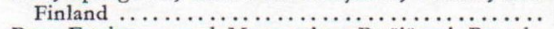 & 350 \\
\hline 22 & Clayey silt. Hämeenkyrö, Komi, Mattila, Finland .. & 66 & 66 & Peat, Equisetum and Menyanthes. Petäjävesi, Puttola, & \\
\hline 23 & Silty clay. Kaavi, Luikonlahti, Lake Retusjärvi, Finland & 180 & & 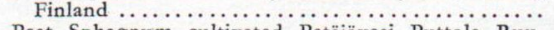 & 250 \\
\hline 24 & Silty clay. Kaavi, Luikonlahti, Finland ........... & 170 & 67 & Peat, Sphagnum, cultivated. Petäjävesi, Puttola, Ruu- & \\
\hline $\begin{array}{l}25 \\
26\end{array}$ & & $\begin{array}{r}59 \\
600\end{array}$ & & kinsuo, Finland $\ldots \ldots \ldots \ldots \ldots \ldots \ldots \ldots \ldots$ & 150 \\
\hline 27 & $\begin{array}{l}\text { Clay. Rome, Narni, Italy }, \ldots \ldots \ldots \ldots \ldots \ldots \ldots \\
\text { Clay. Kuhmoinen, Patavesi, Finland } \ldots \ldots \ldots \ldots \ldots\end{array}$ & $\begin{array}{l}600 \\
500\end{array}$ & 68 & $\begin{array}{l}\text { Peat, Sphagnum. Petäjävesi, Puttola, Ruukinsuo, Fin- } \\
\text { land } \ldots \ldots \ldots \ldots \ldots \ldots \ldots \ldots \ldots \ldots \ldots \ldots \ldots \ldots \ldots \ldots \ldots \ldots \ldots \ldots \ldots \ldots \ldots\end{array}$ & 140 \\
\hline 28 & 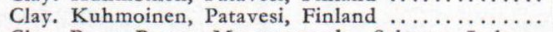 & 490 & 69 & Peat, Sphagnum. Hämeenkyrö, Komi, Mattila, Fin- & \\
\hline 29 & Clay. Prov. Rome, Monterotondo, Salarese, Italy .. & 400 & & 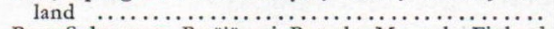 & 115 \\
\hline 30 & Clay, Litorina. Eura, Karhala, Finland $\ldots \ldots \ldots \ldots \ldots$ & 390 & 70 & Peat, Sphagnum. Petäjävesi, Puttola, Maunula, Finland & 54 \\
\hline 31 & $\begin{array}{l}\text { Clay, containing a little humus. Helsinki, Viikki, Fin- } \\
\text { land } \ldots \cdots \cdots \cdots \cdots \cdots \cdots \cdots \cdots \cdots \cdots \cdots \cdots \cdots \cdots \cdots\end{array}$ & 330 & 71 & $\begin{array}{l}\text { Peat, Sphagnum. Petäjävesi, Puttola, Ruukinsuo, Fin- } \\
\text { land } \ldots \ldots \ldots \ldots \ldots \ldots \ldots \ldots \ldots \ldots \ldots \ldots \ldots \ldots \ldots \ldots \ldots \ldots \ldots \ldots \ldots\end{array}$ & 24 \\
\hline $\begin{array}{l}32 \\
33\end{array}$ & $\begin{array}{l}\text { Clay. Huittinen, Finland } \ldots \ldots \ldots \ldots \ldots \ldots \\
\text { Clay, Yoldia. Inkeri, Mga-river, USSR } \ldots \ldots \ldots \ldots\end{array}$ & $\begin{array}{l}260 \\
230\end{array}$ & 72 & $\begin{array}{l}\text { Peat, Sphagnum. Petäjävesi, Puttola, Pappavainaansuo, } \\
\text { Finland } \ldots \ldots \ldots \ldots \ldots \ldots \ldots \ldots \ldots \ldots\end{array}$ & \\
\hline 34 & Clay. Prov. Rome, Monterotondo, Salarese, Italy .. & 210 & 73 & Peat, Sphagnum. Petäjävesi, Puttola, Finland ........ & n.d. \\
\hline 35 & 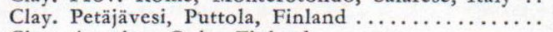 & 140 & 74 & Dy. Hämeenkyrö, Komi, Marjamaa, Finland $\ldots \ldots$. & 84 \\
\hline 36 & Clay, Ancylus. Oulu, Finland $\ldots \ldots \ldots \cdots \cdots \cdots \cdots$ & n.d. & $\begin{array}{l}75 \\
76\end{array}$ & $\begin{array}{l}\text { Dy. Hämeenkyrö, Komi, Mattila, Finland } \ldots \ldots \ldots \\
\text { Gyttja. Petäjävesi, Lake Kirrinjärvi, Finland } \ldots \ldots\end{array}$ & $\begin{array}{r}81 \\
160\end{array}$ \\
\hline & Mineral soils containing humus & & 77 & $\begin{array}{l}\text { Gyttja, contains phlogopite. Siilinjärvi, Lake Särki- } \\
\text { lampi, Finland (Puustinen 1971, 23-28) }\end{array}$ & 44 \\
\hline 37 & Topsoil, raw humus. Kuhmoinen, Patavesi, Finland & 280 & 78 & Calcareous gyttja. Stockholm, Sweden $\ldots \ldots \ldots \ldots \ldots$ & n.d. \\
\hline 38 & Topsoil, raw humus. Helsinki, Herttoniemi, Finland & 260 & 79 & Calcareous detritus sediment. Aland, Finland .... & 450 \\
\hline 39 & $\begin{array}{l}\text { Topsoil, raw humus. Hämeenkyrö, Komi, Majajärvi, } \\
\text { Finland } \ldots \ldots \ldots \ldots \ldots \ldots \ldots \ldots \ldots \ldots \ldots \ldots \ldots \ldots \ldots \ldots\end{array}$ & 130 & 80 & Calcareous detritus sediment, Mytilidae. Vänesborg, & 230 \\
\hline 40 & Topsoil, raw humus. Helsinki, Herttoniemi, Finland & 130 & 81 & Calcareous detritus sediment, Postglacial, Mytilidac. & \\
\hline $\begin{array}{l}41 \\
42\end{array}$ & $\begin{array}{l}\text { Topsoil, raw humus. Petäjävesi, Puttola, Finland .. } \\
\text { Topsoil, raw humus. Petäjävesi, Maunula, Finland }\end{array}$ & $\begin{array}{r}120 \\
95\end{array}$ & & Kantalahti, Kujärska, East-Karelia, USSR ...... & 110 \\
\hline 43 & $\begin{array}{l}\text { Topsoil, forest mull humus. Petäjävesi, Puttola, Kont- } \\
\text { tila, Finland } \ldots \ldots \ldots \ldots \ldots \ldots \ldots \ldots \ldots \ldots \ldots \ldots \ldots \ldots\end{array}$ & 16 & 82 & $\begin{array}{l}\text { Shell, weathered oyster, Pelecypoda, from the ancient } \\
\text { shore of the Arctic Ocean. Petsamo, USSR (Gaarder }\end{array}$ & \\
\hline 44 & $\begin{array}{l}\text { Topsoil, raw humus. Hämeenkyrö, Komi, Mattila, } \\
\text { Finland } \ldots \ldots \ldots \ldots \ldots \ldots \ldots \ldots \ldots \ldots \ldots \ldots \ldots \ldots\end{array}$ & n.d. & & and Bjerkan 1934) $\ldots \ldots \ldots \ldots \ldots \ldots \ldots \ldots$ & 20 \\
\hline 45 & Topsoil, forest mull humus. Helsinki, Laa jasalo, Ta h- & & & Miscellaneous sediments & \\
\hline & 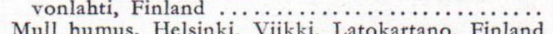 & & 83 & Kaolinite. Monte Kaolino, Bavaria, West Germany & \\
\hline 46 & Mull humus. Helsinki, Viikki, Latokartano, Finland & 510 & 84 & Bauxite. Meleyes Banya, Gant, Hungary ......... & 170 \\
\hline
\end{tabular}

\section{Kaolinite and bauxite}

Only one sample of each was analyzed (Table 1 , Nos. 83-84). These soils contain mostly aluminium hydroxides along with some water and silica and are more weathered than the other soils investigated. The fact that they contain selenium $s$ interesting. It may be tentatively proposed that

aluminium hydroxide, like iron hydroxide, can bind selenium chemically and prevent its dissolution.

The present results are in accordance with the laboratory investigations of Jones and Belling (1967, 737). In their findings, $25-62 \%$ of dissolved sodium selenate was adsorbed by lateritic soils. 


\section{Conclusions}

Tentative averages for the selenium contents of sediments in Finland, representing only orders of magnitude, are:

Se, $\mathrm{ppb}$

64

Till .......................

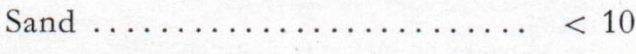

Silt $\ldots \ldots \ldots \ldots \ldots \ldots \ldots \ldots \ldots$

Clayey silt, Silty clay ......... 140

Clav .................. 320

Organic mineral soils ........ 180

Peat $\ldots \ldots \ldots \ldots \ldots \ldots \ldots \ldots .120$

Mud, Gyttja ............. 75

Calcareous detritus sediments .... 200

These averages illustrate the differentiation of selenium during exogenic processes.

In magmatic and metamorphic processes, selenium substitutes for sulphur in sulphides. In exogenic processes, however, selenium usually oxidizes to elemental form or to selenite ( $c f$. Dyachkova and Khodakovskiy 1968), whereas sulphur oxidizes to sulphate. The behavior of the two elements is thus different. Because the selenium content of the underlying bedrock is low (Koljonen 1973b; c; d), the selenium contents of Finnish soils are probably lower than average (cf. Leutwein 1972, 34-K-1-3). Moreover, selenium in elemental form tends to become fixed in colloids or, as iron selenite, forms soluble compounds only with some difficulty. Consequently, its deficiency as a nutrient is likely over large areas of Finland ( $c f$. Lakin 1972). Even such deficiency diseases as nutritional muscular degeneration (NMD) in ruminants (Oksanen 1965, 191; Oksanen and Sandholm 1970) may be caused by the low selenium contents in soils.

Acknowledgments - The author wishes to thank Professor Th. G. Sahama for his helpful comments and advice on many points. Dr. Kathleen Ahonen assisted with the English-language text.

\section{REFERENCES}

BAKER, W. E. (1973) The role of humic acids from Tasmanian podzolic soils in mineral degradation and metal mobilization. Geochim. Cosmochim. Acta 37, $269-281$.

Beath, O. A. and Gilbert, C. S. (1936) Seleniumbearing vegetation during late Cretaceous time. Science 84 , No. $2187,484-485$.

Beath, O. A., Hagner, A. F. and Gilbert, C. S. (1946) Some rocks and soils of high selenium content. Wyo. Geol. Surv. Bull. 36.

Byers, H. G. and Knight, H. G. (1935) Selenium in soils. Ind. Eng. Chem., Ind. Ed., 27, 902-904.

CARlson, L. (1973) Tärkeimpien mineraalien ja pääalkuaineiden vertikaalinen jakauma neljän dystrofisen järven pohjasedimenteissä Lounais-Suomessa. Unpubl. thesis, Arch. Dep. Geol. Miner., Univ. Helsinki.

Chentsov, I. G. (1963) Selenium in Paleogene deposits of Central Asia. Miner. Abstr. 15, 189-190.

Davidson, D. F. and Gulbrandsen, R. A. (1957) Selenium in the Phosphoria formation in Idaho, Wyoming, Utah, and Montana. Bull. Geol. Soc. Am. 68,1714

Delahay, P., Pourbaix, P. and van Rysselberghe, P. (1952) Diagrammes d'équilibre potentiel $\mathrm{pH}$ de quelques éléments. C. R. Réunion du Comité Thermodynamique Cinét. Electrochim. Milano.

Dyachkova, J. B. and Khodakovskiy J. L. (1968) Thermodynamic equilibria in the systems $\mathrm{S}-\mathrm{H}_{2} \mathrm{O}$, $\mathrm{Se}-\mathrm{H}_{2} \mathrm{O}$ and $\mathrm{Te}-\mathrm{H}_{2} \mathrm{O}$ in the $25-300^{\circ}$ temperature range and their geochemical interpretations. Geokhimiya 5, 1108.

Fleming, G. A. and Walsh, T. (1957) Selenium occurrence in certain Irish soils and its toxic effects on animals. R. Ir. Acad. Proc. 58, Sec. B, 151-166.

GaArder, T. and Bjerkan, P. (1934) Østers og østersrkultur i Norge. A. s. John Griegs Bogtrykkeri, Bergen.

Gibson, F. H. and Selvig, W. A. (1944) Rare and uncommon chemical elements in coal. U.S. Bur. Mines, Tech. Pap. 669.

Goldschmidt, V. M. and Strock, L. W. (1935) Zur Geochemie des Selens, II. Nachr. Ges. Wiss. Gött., Math.-Phys. K1., 4, 123-142.

Jones, G. B. and Belling, G. B. (1967) The movement of copper, molybdenum, and selenium in soils as indicated by radioactive isotopes. Aust. J. Agric. Res. $18,733-740$. 
Keys, W. S. and White, R. L. (1956) Investigation of the Temple Mountain collapse and associated features, San Rafael Swell, Emery County, Utah, in Contributions to the geology of uranium and thorium by the United Nations International Conference on Peaceful Uses of Atomic Energy, Geneva, Switzerland, 1955. U.S. Geol. Surv., Prof. Pap. 300, 285-298.

Koljonen, T. (1965) Seleenin esiintymisestä suomalaisissa kivissä. Unpubl. manuscr., Arch. Dep. Geol. Miner., Univ. Helsinki.

- (1973a) Determination of selenium in rocks, soils, and plants. Suomen Kemistil. 46 B, 133-138.

- (1973b) Seleniun in certain igneous rocks. Bull. Geol. Soc. Finl. 45, 9-22.

- (1973c) Selenium in certain metamorphic rocks. Bull. Geol. Soc. Finl. 45, 107-117.

- (1973d) Selenium in certain sedimentary rocks. Bull. Geol. Soc. Finl. 45, 118-123.

LAKIN, H. W. (1972) Selenium accumulation in soils and its absorption by plants and animals. Geol. Soc. Am. Bull. 83, 181- 190 .

Leutwern, F. (1972) Selenium. Biochemistry, 34-L-12. Handbook of Geochemistry II-3 (Ed. Wedepohl, K. H.).

Meixner, H. (1954) Neue Mineralfunde in der österreichischen Ostalpen XIII. Carinthia II 64, $18-29$.
OKsanen, H. (1965) Studies on nutritional muscular degeneration (NMD) in ruminants. Acta Vet. Scand., Suppl. 2.

- and SANDHOLM, M. (1970) The selenium content of Finnish forage crops. J. Sci. Agric. Soc. Finl. 42, $250-253$.

Oldfield, J. E. (1972) Selenium deficiency in soils and its effect on animal health. Bull. Geol. Soc. Am. 83, $173-180$.

Punstinen, Kauko (1971) Geology of the Siilinjärvi carbonatite complex, eastern Finland. Bull. Comm. géol. Finl. 249.

Rosenfeld, Irene and Beath, O. A. (1964) Selenium; geobotany, biochemistry, toxicity, and nutrition. Academic Press, New York-London.

Searight, W. V., Moxon, A. L., Hillmoe, R. J. and Whitehead, E. L. (1946) Occurrence of selenium in Pleistocene deposits and their derivatives in South Dakota. Soil Sci. 61, 455-463.

Trelease, S. F. and Beath, O. A. (1949) Selenium, its geological occurrence and its biological effects in relation to botany, chemistry, agriculture, nutrition, and medicine. Publ, auth., New York.

Walsh, T., Fleming, G. A., O'Connor, R. and Sweeney, A. (1951) Selenium toxicity associated with an Irish soil series. Nature 168.

WedepoHL, K. H. (1972) Handbook of Geochemistry II-3. Springer-Verlag, Berlin-Haidelberg-New York.

Manuscript received, July 3, 1973. 